\title{
Mental health and physical inactivity during pregnancy: a cross-sectional study nested in the BRISA cohort study
}

\author{
Saúde mental e inatividade física durante a \\ gestação: estudo transversal aninhado \\ no estudo de coorte BRISA \\ La salud mental y la inactividad física durante el \\ embarazo: estudio transversal anidado \\ en la cohorte BRISA
}

Eliana Harumi Morioka Takahasi ${ }^{1}$ Maria Teresa Seabra Soares de Britto e Alves 1 Gilberto Sousa Alves 2

Antônio Augusto Moura da Silva 1 Rosângela Fernandes Lucena Batista 1 Vanda Maria Ferreira Simões 1 Cristina Marta Del-Ben 3 Marco Antonio Barbieri 3

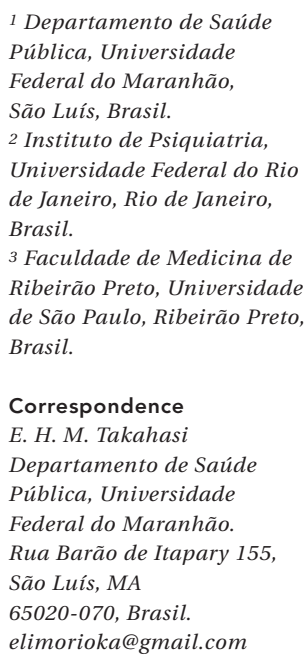

${ }^{3}$ Faculdade de Medicina de Ribeirão Preto, Universidade de São Paulo, Ribeirão Preto, Brasil.

Correspondence E. H. M. Takahas Departamento de Saúd Pública, Universidade Federal do Maranhão. Rua Barão de Itapary 155, São Luís, MA

65020-070, Brasil. elimorioka@gmail.com

\begin{abstract}
The aim of this study was to investigate the association between mental health and physical inactivity in 1,447 pregnant women in the second trimester of pregnancy. Subjects answered the short version of the International Physical Activity Questionnaire. Symptoms of depression and anxiety, and stress levels were assessed using the Center for Epidemiological Studies Depression Scale, the Beck Anxiety Inventory and the Perceived Stress Scale, respectively. The rate of physical inactivity was low (39.8\%). The prevalence rates of symptoms of severe depression and severe levels of anxiety were $28.8 \%$ and $16.9 \%$, respectively. The average perceived stress score was 24.9. An association was found between physical inactivity and not living with a partner $(O R=$ 1.28), having a manual occupation $(O R=0.71)$ and, unexpectedly, normal and low levels of anxiety $(O R=1.46$ and $O R=1.44$, respectively). No association was observed between physical inactivity and symptoms of severe depression and perceived stress. It is plausible to assume that the majority of physical activity practiced by these women was attributable to housework or occupation which may in turn be associated with high levels of anxiety.
\end{abstract}

Mental Health; Motor Activity; Pregnancy

\section{Resumo}

O objetivo do estudo foi analisar a associação entre indicadores de saúde mental e a inatividade física em amostra com 1.447 mulheres no 2 o trimestre gestacional, que responderam ao Questionário Internacional de Atividade Física - versão curta, à Escala de Rastreamento Populacional para Depressão do Centro de Estudos Epidemiológicos, à Escala de Ansiedade de Beck $e$ à Escala de Estresse Percebido. A taxa de inatividade física foi baixa (39,8\%), sintomas depressivos graves estiverem presentes em $28,8 \% d a$ amostra e nível de ansiedade intensa em 16,9\%. O escore médio de estresse percebido foi de 24,9. Não residir com companheiro $(R P=1,28)$, função ocupacional manual $(R P=0,71)$ e, ao contrário do esperado, níveis de ansiedade normal $(R P=1,46)$ e leve $(R P=1,44)$ apresentaram associação com a inatividade física. Não houve associação entre estresse e sintomas de depressão com a inatividade física. É possível que nas mulheres desta amostra uma parcela importante da atividade física esteja ligada a atividades domésticas ou laborais, que poderiam estar associadas a maiores níveis de ansiedade.

Saúde Mental; Atividade Motora; Gravidez 


\section{Introduction}

Current guidelines suggest that, in the absence of medical or obstetric complications, pregnant women should practice at least 30 minutes of moderate physical activity a day 1,2 . However, activities that involve a high risk of falling and prolonged exercise (more than 45 minutes), especially in hot and humid conditions, should be avoided 3 .

In a population based study carried out in the State of São Paulo, Zanchetta et al. 4 observed a physical inactivity rate of $12.9 \%$ among women aged between 18 and 29 years. Despite current recommendations and reported benefits for mother and child, physical activity, especially sports and exercise, decreases during pregnancy ${ }^{5}$. The rate of physical inactivity during pregnancy is high, ranging from $64.5 \%$ to $91.5 \%$ $6,7,8,9,10,11$, and tends to be lower in the third trimester of pregnancy 12,13 . In addition, physical inactivity during pregnancy is associated with an increased probability of admission of infants to neonatal intensive care units, preterm delivery 14 , low birth weight, intrauterine growth restriction 15 , cesarean sections and stillbirths 11 .

Recent studies that focused on understanding the determinants and correlates of physical activity among pregnant women 16 show that lower levels of education and socioeconomic status, and unemployment are factors associated with reduced levels of physical activity during pregnancy 6,11,17,18.

It is important to obtain a better understanding of the barriers to practicing physical activity, especially those related to mental health 19,20. Women are more vulnerable to mental health problems during pregnancy due to the intense psychological and biological changes that occur during this period 19,21. The prevalence of symptoms of depression, stress and 12-month prevalence rate of anxiety in women who are not pregnant is $5.9 \% 22,79.3 \% 23$ and $11 \% 24$, respectively, while prevalence rates of symptoms of depression, anxiety and perceived stress in pregnant women vary between 12.8 and $25 \% 25,26,19.827$ and $64.9 \% 28$, and $78 \% 29,30$ and $93 \% 31$, respectively. Such changes in mental health can result in adverse health outcomes for mother and child, including preterm birth and low birth weight 32 . Evidence also suggests that depression and stress during pregnancy are risk factors for psychiatric disorders during the postpartum period 33 .

The relationship between mental health and physical activity during pregnancy is complex. Tendais et al. 9 found that symptoms of depression were stable during pregnancy, but psychological well-being decreased among pregnant women that were inactive during the first trimester of pregnancy. Poorer mental health status associated with pregnancy may be a contributing factor to reduced activity as physical effort becomes less attractive and more difficult 19 . On the other hand, studies of population samples of nonpregnant women show that regular exercise can alleviate psychological complaints and lead to improvements in quality of life $34,35,36,37,38,39,40,41,42$.

Studies of samples of pregnant women corroborate these findings. Physical activity during pregnancy has been shown to provide mood stability 43 and a cross-sectional study found an inverse association between physical activity and symptoms of depression in pregnant women 44 . Evidence also shows that participation in aerobic exercise programs reduces the occurrence of symptoms of depression during pregnancy 45,46 . However, the association between physical activity and symptoms of depression differs depending on the type of activity: the practice of moderate or vigorous-intensity physical activity reduces the likelihood of symptoms of severe depression, whereas activities related to adult or child care and household chores have the opposite effect 4 . It has also been observed that symptoms of anxiety are less prevalent in women who practice recreational physical activity 48 . On the other hand, Segato et al. 31 found no difference in the prevalence of stress symptoms when comparing physically active and inactive pregnant women.

The mechanisms involved in the association between mental health and physical activity remain open to debate. Studies suggest a complex interaction between psychological and neurobiological factors $34,35,36$ and the intensity, frequency, duration and type of physical activity 35 .

Despite the frequency of physical inactivity and mental disorders during pregnancy, the relationship between these two states remains unclear, and a better understanding of these factors is important to assure improvements in mother and child care strategies.

The main aims of this study were: (1) to classify levels of physical activity and identify the rate of physical inactivity among pregnant women; (2) to evaluate mental health status through the assessment of symptoms of depression and anxiety and perceived stress levels; (3) to analyze the association between mental health and physical inactivity. We hypothesized that higher levels of anxiety, depression and perceived stress in pregnant women are associated with physical inactivity during pregnancy. 


\section{Methods}

A cross-sectional study of 1,447 pregnant women attending private and public hospitals in the municipality of São Luís, State of Maranhão in the Northeast of Brazil was conducted between March 2010 and June 2011. This project was nested in the cohort study Etiology of Preterm Birth and Consequences of Perinatal Outcomes for Child Health: Birth Cohorts in Two Brazilian Cities - BRISA (acronym in Portuguese), carried out in São Luís and in the city of Ribeirão Preto in the State of São Paulo beginning in 2010. Due to the lack of availability of listing, it was not possible to obtain a random sample of pregnant women and therefore the study was conducted using a convenience sample. Women resident in the municipality and who agreed to participate in the study were recruited in selected prenatal care and ultrasound settings. Since one of the main objectives of the BRISA cohort is to study risk factors for preterm delivery, women were included in the sample only if they had performed an ultrasound before the twentieth week of pregnancy.

This sample size has a power of $80 \%$ to identify differences in the rate of physical inactivity among women with a probability of type I error of $5 \%$.

Outpatients between the twenty-second and twenty-fifth weeks of gestation, confirmed by an obstetric ultrasound performed before the twentieth week were considered eligible for interview. This period was chosen to avoid the possibility of miscarriage and to identify mental health problems as early as possible during pregnancy.

Data was obtained using a questionnaire which the women filled out with the aid of interviewers. The interviewers were trained to ensure standardization of data collection. Data input was carried out by two separate typists and the accuracy of the two datasets was then tested through comparison and correction of inconsistencies.

\section{Variables}

\section{- Level of physical activity}

Level of physical activity was assessed using the short version of the International Physical Activity Questionnaire (IPAQ) validated for use with the Brazilian population by Matsudo et al. 49 and previously tested with samples of pregnant women 8,9 . We evaluated energy expenditure in metabolic equivalents (MET) for three specific types of activities: walking, moderate-intensity physical activities and vigorous-intensity physical activities 50. MET-minutes/week were defined by multiplying the standard MET value for each activity by the time spent (in minutes) per day doing the activity multiplied by the number of days per week that the activity was performed 50 as follows: walking $=3.3 \mathrm{x}$ time (minutes) $\mathrm{x}$ days; moderate-intensity activity $=4.0 \mathrm{x}$ time (minutes) $\mathrm{x}$ days; and vigorous-intensity activity $=8.0 \mathrm{x}$ time (minutes) $\mathrm{x}$ days. The total physical activity METminutes/week is the sum of the MET-minutes/ week for each activity.

Level of physical activity was initially classified into the following three categories 50 :

(a) High: a vigorous-intensity activity practiced at least three days a week, comprising a minimum total of 1,500 MET-minutes/week, or at least seven days of any combination of walking, moderate-intensity or vigorous-intensity activity, comprising a minimum total of 3,000 METminutes/week;

(b) Moderate: a vigorous-intensity activity practiced for at least 20 minutes a day three days a week, or moderate-intensity activity and/or walking practiced for at least 30 minutes a day five days a week, or any combination of walking, moderate-intensity or vigorous-intensity activity practiced at least five days a week and comprising a minimum total of 600 MET-minutes/week; (c) Low: physical activity that does not meet the above criteria.

Those women in the moderate category meet the American Congress of Obstetricians and Gynecologists (ACOG) recommendation regarding physical activity during pregnancy (at least 30 minutes of physical activity on most or all days of the week) 1 . Two categories were therefore created to classify levels of physical inactivity: active individuals (which included moderate and high levels of activity) and inactive individuals (low level of physical activity).

\section{- Sociodemographic variables}

The following sociodemographic variables were analyzed: maternal age (under 20 years; 20 to 34 years; and 35 years and over); level of education (less than nine years; nine to 11 years; and at least 12 years of study); occupation (non-manual; manual; and unemployed); socioeconomic status, defined based on the Economic Classification Criterion for Brazil developed by the Associação Brasileira de Empresas de Pesquisa (http://www. abep.org/novo/Content.aspx?ContentID $=301$, accessed on 17/Dec/2012). The ABEP categorization allows the estimation of the purchasing power of urban households which are grouped into the following income classes: A1, A2, B1 and B2 into category A/B; C1 and C2 into category $\mathrm{C}$; and D and E into category D/E. Category A/B includes individuals in the upper socioeconomic 
status groups, whereas classes D/E comprise low socioeconomic status groups. Whether the mother lived alone or with a family member (e.g., spouses and children) was also considered.

\section{- Symptoms of depression}

Symptoms of depression were identified using the Center for Epidemiologic Studies Depression Scale (CES-D) 51. The scale was developed for use in populations with no known history of mental illness and assesses the intensity of depressive symptoms and has been previously tested with pregnant women 52 .

The CES-D comprises 20 items and identifies the presence of salient symptoms of depression, such as depressed mood, feelings of guilt and worthlessness, feelings of helplessness and hopelessness, psychomotor retardation, loss of appetite and sleep disturbance 51. Four items were worded in the positive direction. Each response was scored from zero to three based on the frequency of occurrence of the symptom and positive items were reversed scored. CES-D scores range from zero to 60 , where higher scores indicate a greater number of symptoms. According to recommendations made by a previous study, a cutoff score of $\geq 22$ was used to represent "symptoms of severe depressive" 52 .

\section{- Symptoms of anxiety}

The presence of anxiety symptoms was assessed using the Beck Anxiety Scale (BAI), which has been validated for use with pregnant women 53 The scale is usually used to carry out a clinical assessment of anxiety, but is also an appropriate tool for screening individuals with anxiety disorders from the general population 54 . The BAI is a 21-item questionnaire designed to assess the severity of anxiety symptoms. Respondents rate the extent to which they were affected by each symptom during the past week on a scale of zero (not at all) to three (severely) 53 . Anxiety level is classified based on the total score as follows; normal (zero-nine points), mild (10-18 points), moderate (19-29 points) and severe (30-63 points) 55 .

\section{- Perceived stress}

The perceived stress level was analyzed using the Perceived Stress Scale (PSS-14) 56, a short selfreport questionnaire translated and validated for use with the Brazilian population 57 . The PSS-14 consists of 14 items designed to measure the perception of stressful life events during the previous four weeks. The questionnaire is rated using a five-point scale ranging from zero (never) to four (always), with a minimum total score of zero and a maximum of 5656 . The PSS-14 has been used with both clinical and non-clinical samples, including pregnant women 31,58. Recommendations suggested by Deslandes et al. 36 were followed in order to achieve a more accurate estimation of higher levels of perceived stress among the sample. Subjects with scores within the highest quartile were categorized as being subject to a severe level of perceived stress.

\section{Statistical analysis}

Data was analyzed using the Stata version 10.0 software (Stata Corp., College Station, USA). Descriptive statistics (means with standard deviations or frequency distribution) of sociodemographic variables, physical inactivity and mental health variables were computed.

The dependent variable was level of physical activity (physically active or inactive). Unadjusted and adjusted analysis of the factors associated with physical inactivity was conducted using robust Poisson regression adopting a significance level of 0.05 .

\section{Ethical aspects}

This research meets the criteria of the Resolution 196/96 of the Brazilian National Health Council and its complementary norms. Informed written consent was obtained from all subjects after they had received a detailed explanation about the study protocol. This study was approved by the local Ethics Committee (process number 4771/2008-30)

\section{Results}

Table 1 depicts the sociodemographic characteristics of the cohort sample of 1,447 pregnant women: $81 \%$ of the sample were aged between 20 and 34 years, $75.4 \%$ had between nine and 11 years of study, $79.8 \%$ were living with a partner, $57.4 \%$ were not living with children and $64.4 \%$ were from economic class $\mathrm{C}$. The majority of the sample were unemployed and had manual occupations.

The rate of physical inactivity was $39.8 \%$. Symptoms of severe depression (CES-D $\geq 22$ ) were observed in $28.8 \%$ of the sample and $16.9 \%$ of the pregnant women experienced severe levels of anxiety (BAI $\geq 30$ ). The average perceived stress level was 24.9 (Table 2).

The results of the unadjusted analysis (Table 3) show that subjects under 20 years of age $(\mathrm{OR}=1.28 ; \mathrm{p}=0.002)$, living without a partner 
Table 1

Sociodemographic characteristics of a sample of pregnant women $(N=1,447)$ from São Luís, State of Maranhão, Brazil, 2010 to 2011.

\begin{tabular}{lcc}
\hline Characteristic & $\mathbf{n}$ & $\%$ \\
\hline Age (years) & 178 & 12.3 \\
$<20$ & 1,172 & 81.0 \\
$20-34$ & 97 & 6.7 \\
$>34$ & & \\
Education (years) & 183 & 12.7 \\
$<9$ & 1,090 & 75.4 \\
$9-11$ & 172 & 11.9 \\
$>11$ & & \\
Living with a partner & 1,154 & 79.8 \\
Yes & 292 & 20.2 \\
No & & \\
Living with children & 616 & 42.6 \\
Yes & 831 & 57.4 \\
No & & \\
Employment & 240 & 16.6 \\
Non-manual occupation & 451 & 31.2 \\
Manual occupation & 754 & 52.2 \\
Unemployed & & \\
Economic class & 289 & 20.0 \\
A/B & 932 & 64.4 \\
C & 226 & 15.6 \\
D/E & & \\
\hline
\end{tabular}

Table 2

Levels of physical activity and mental health status of a sample of pregnant women $(N=1,447)$ from São Luís, State of Maranhão, Brazil, 2010 to 2011.

\begin{tabular}{|c|c|c|c|}
\hline Variable & $\mathbf{n}$ & $\%$ & Mean \pm SD \\
\hline \multicolumn{4}{|l|}{ Level of physical activity } \\
\hline Low & 576 & 39.8 & \\
\hline Moderate & 607 & 42.0 & \\
\hline High & 264 & 18.2 & \\
\hline \multicolumn{4}{|c|}{ Symptoms of severe depression } \\
\hline No & 1,026 & 71.3 & \\
\hline Yes & 414 & 28.8 & \\
\hline \multicolumn{4}{|l|}{ Anxiety level } \\
\hline Normal & 387 & 26.8 & \\
\hline Mild & 469 & 32.4 & \\
\hline Moderate & 346 & 23.9 & \\
\hline Intense & 245 & 16.9 & \\
\hline Perceived stress level & & & $24,9 \pm 8,3$ \\
\hline
\end{tabular}


Unadjusted analysis of the variables associated with physical inactivity in a sample of pregnant women from São Luís, State of Maranhão, Brazil, 2010 to 2011.

\begin{tabular}{|c|c|c|c|}
\hline Variable & OR * & $95 \% \mathrm{Cl}$ & p-value ** \\
\hline Age (years) & & & 0.002 \\
\hline$<20$ & 1.00 & & \\
\hline $20-34$ & 1.28 & $1.09 ; 1.51$ & \\
\hline$>34$ & 0.77 & $0.56 ; 1.05$ & \\
\hline Education (years) & & & 0.743 \\
\hline$<9$ & 1.00 & & \\
\hline $9-11$ & 1.00 & $0.83 ; 1.22$ & \\
\hline$>11$ & 1.08 & $0.84 ; 1.39$ & \\
\hline Living with a partner & & & 0.001 \\
\hline Yes & 1.00 & & \\
\hline No & 1.28 & $1.12 ; 1.48$ & \\
\hline Living with children & & & 0.002 \\
\hline Yes & 1.00 & & \\
\hline No & 1.24 & $1.08 ; 1.41$ & \\
\hline Employment & & & $<0.001$ \\
\hline Non-manual occupation & 1.00 & & \\
\hline Manual occupation & 0.69 & $0.57 ; 0.84$ & \\
\hline Unemployed & 0.90 & $0.77 ; 1.05$ & \\
\hline Economic class & & & 0.060 \\
\hline $\mathrm{A} / \mathrm{B}$ & 1.00 & & \\
\hline C & 0.84 & $0.73 ; 0.98$ & \\
\hline$D / E$ & 0.82 & $0.67 ; 1.02$ & \\
\hline Anxiety level & & & 0.001 \\
\hline Normal & 1.00 & & \\
\hline Mild & 1.22 & $0.96 ; 1.55$ & \\
\hline Moderate & 1.46 & $1.17 ; 1.82$ & \\
\hline Intense & 1.50 & $1.20 ; 1.87$ & \\
\hline Symptoms of severe depression & & & 0.039 \\
\hline No & 1.00 & & \\
\hline Yes & 1.17 & $1.01 ; 1.36$ & \\
\hline Stress & & & 0.115 \\
\hline Yes & 1.00 & & \\
\hline No & 1.13 & $0.97 ; 1.32$ & \\
\hline
\end{tabular}

OR: odds ratio; $95 \% \mathrm{Cl}$ : $95 \%$ confidence interval.

* OR estimated using robust Poisson regression;

** $p$-value resulting from the log-likelihood test.

$(\mathrm{OR}=1.28 ; \mathrm{p}=0.001)$ or children $(\mathrm{OR}=1.24 ;$ $\mathrm{p}=0.002$ ) were more likely to present higher rates of physical inactivity, whereas having a manual occupation $(\mathrm{OR}=0.69 ; \mathrm{p}<0.001$ ) was associated with lower rates of physical inactivity. No association was found between education and economic status and level of physical activity. The rate of physical inactivity in pregnant women presenting mild or normal levels of anxiety was $46 \%$ and $50 \%$ higher, respectively, than in wom- en subject to severe levels of anxiety ( $p=0.001)$. The presence of symptoms of severe depression was associated with a $17 \%$ higher rate of physical inactivity ( $p=0.039$ ). No association was found between perceived stress and physical inactivity $(\mathrm{p}=0.115)$.

The results of the adjusted analysis (Table 4) show that there was a significant association between physical inactivity and the following factors: mild $(\mathrm{OR}=1.44)$ or normal anxiety levels 
Table 4

Adjusted analysis of the variables associated with physical inactivity in a sample of pregnant women from São Luís, State of Maranhão, Brazil, 2010 to 2011.

\begin{tabular}{|c|c|c|c|}
\hline Variable & OR * & $95 \% \mathrm{Cl}$ & $\mathrm{p}$-value ** \\
\hline Age (years) & & & 0.156 \\
\hline$<20$ & 1.00 & & \\
\hline $20-34$ & 1.12 & $0.94 ; 1.34$ & \\
\hline$>34$ & 0.80 & $0.59 ; 1.09$ & \\
\hline Education (years) & & & 0.973 \\
\hline$<9$ & 1.00 & & \\
\hline $9-11$ & 0.98 & $0.80 ; 1.19$ & \\
\hline$>11$ & 0.98 & $0.75 ; 1.28$ & \\
\hline Living with a partner & & & 0.001 \\
\hline Yes & 1.00 & & \\
\hline No & 1.28 & $1.11 ; 1.48$ & \\
\hline Living with children & & & 0.066 \\
\hline Yes & 1.00 & & \\
\hline No & 1.14 & $0.99 ; 1.31$ & \\
\hline Employment & & & 0.002 \\
\hline Non-manual occupation & 1.00 & & \\
\hline Manual occupation & 0.71 & $0.58 ; 0.86$ & \\
\hline Unemployed & 0.88 & $0.74 ; 1.05$ & \\
\hline Economic class & & & 0.256 \\
\hline$A / B$ & 1.00 & & \\
\hline C & 0.88 & $0.76 ; 1.02$ & \\
\hline $\mathrm{D} / \mathrm{E}$ & 0.92 & $0.74 ; 1.14$ & \\
\hline Anxiety level & & & 0.008 \\
\hline Normal & 1.00 & & \\
\hline Mild & 1.21 & $0.95 ; 1.53$ & \\
\hline Moderate & 1.44 & $1.14 ; 1.82$ & \\
\hline Intense & 1.46 & $1.14 ; 1.86$ & \\
\hline Symptoms of severe depression & & & 0.610 \\
\hline No & 1.00 & & \\
\hline Yes & 1.05 & $0.88 ; 1.25$ & \\
\hline Stress & & & 0.873 \\
\hline Yes & 1.00 & & \\
\hline No & 0.99 & $0.82 ; 1.18$ & \\
\hline
\end{tabular}

OR: odds ratio; $95 \% \mathrm{Cl}$ : $95 \%$ confidence interval.

* OR estimated using robust Poisson regression;

** p-value resulting from the log-likelihood test.

$(\mathrm{OR}=1.46 ; \mathrm{p}=0.008) ;$ not living with a partner $(\mathrm{OR}=1.28 ; \mathrm{p}=0.001)$; and having a manual occupation $(\mathrm{OR}=0.71 ; \mathrm{p}=0.002)$.

\section{Discussion}

This study tested the hypothesis that there is an association between the occurrence of mental health complaints in pregnant women, such as anxiety, depression and perceived stress, and the absence of physical activity. Unexpectedly, physically inactive women in the second trimester of pregnancy showed lower levels of anxiety. Furthermore, no significant association was found between having symptoms of depression and perceived stress and physical inactivity after conducting adjusted analysis.

The majority of similar studies involving samples of the general population and pregnant 
women found an association between symptoms of depression $34,35,36,37,45,46$, anxiety 37,48 and stress 41 and lower levels of specific types of leisure-time physical activity and/or exercise. Exercise is a type of leisure-time physical activity that aims to maintain or improve one or more aspects of physical fitness and is planned, structured, systematic, and generally more intense 59 . The apparently contradictory findings of an association between lower anxiety levels and increased physical inactivity can be justified, at least in part, by the instrument used to assess physical activity. The short version of the IPAQ assesses physical activity undertaken during leisure time, domestic and gardening activities, work-related activities and transport-related activities, but does not allow for specific estimates of time spent on each type of physical activity 50 .

Furthermore, patterns of physical activity 16 , and therefore mental health, may be affected by sociodemographic profile. Given the sociodemographic profile of the sample (mainly young women with only primary school education, belonging to economic class $\mathrm{C}$ and unemployed or engaged in manual occupations), it is possible that most physical activity was related to domestic chores and/or work activities, which in turn could be associated with increased anxiety levels. In Brazil, housework and childcare are generally performed by women, while men typically assume the role of provider 60,61 . It can therefore be assumed that the high rate of physical activity found in the sample is probably due to activities related to housework or childcare and, since some women may consider increased housework a burden, this situation may be associated with a greater likelihood of symptoms of severe depression 47 .

Housework involves repetitive tasks with little autonomy 62 and is generally undervalued 63 and therefore may be associated with different forms of mental illness in women 60 , meaning that mental health is likely to be significantly worse in housewives than in formal workers 64 .

The rate of physical inactivity in the second trimester of pregnancy (39.8\%) was lower than that reported in the literature. Two previous studies that used similar instruments to measure physical activity (long version of the IPAQ) among women in the same gestational trimester reported rates of $64.5 \% 9$ and $87.5 \%$. It must be emphasized, however, that these studies used different cutoff points (at least 150 minutes of physical activity per week) 8,9 . A populationbased study carried out by Evenson et al. 6 using an instrument that classified level of physical activity based on metabolic equivalents, reported that $84.2 \%$ of pregnant women were physi- cally inactive. Tavares et al. 10 developed their own questionnaire similar to that of this study and showed that most pregnant women in the second trimester practiced insufficient physical activity. Dumith et al. 11 found that $68.2 \%$ of mothers reported not having practiced physical activity during pregnancy, while another study 7 reported that $91.5 \%$ of pregnant women did not perform leisure-time physical activity in the second trimester of pregnancy. It is likely that these discrepancies reflect differences in the demographic profile of the samples and methodological differences involving the definition of physical activity and inactivity, the type of instrument used and types of physical activity analyzed (leisure-time, work-related, household activities, transport-related). As mentioned above, it is possible that the majority of time spent on physical activity reported by this sample consists of housework and manual occupational activities. Time spent on work-related activities throughout pregnancy remained stable in comparison to the pre-pregnancy pattern ${ }^{9}$. The practice of leisure-time physical activity, which is more likely to decrease during pregnancy 7,9 , is more common in populations with higher levels of education and socioeconomic status 6 .

A systematic review of women in the second trimester of pregnancy conducted by Bennett et al. 25 found that the rate of symptoms of severe depression was $12.8 \%$ (95\%CI: 10.7; 14.8). The high rate of symptoms of severe depression observed by the present study $(28.8 \%$ higher than the rate reported by Bennett et al. 25) may be explained by the fact that more than half of the sample were unemployed. Previous studies have observed an association between symptoms of depression and unemployment 65 and the perception of equity regarding housework 66. Furthermore, the psychopathology of depression can be conceived as a multidimensional construct, and the severity of symptoms may be influenced by low quality of life and other subjective aspects 67 not addressed by this study.

The anxiety rate observed by this study (16.9\%) was relatively low compared to similar studies that observed prevalence rates between $19.8 \% 27$ and $64.9 \% 28$. These differences may reflect methodological issues related to research design, sample size and characteristics. However, the findings of this study suggest that mood alterations are an important aspect that deserves further study and monitoring during pregnancy. The mean perceived stress score was 24.9 , which is similar to that described by Cohen et al. 56 (25.6) in a study of a community sample of women, but lower than that observed by other studies, such as those carried out by Segato et al. 31 and Rondo 
et al. 58 , that reported mean scores of 28.8 and 30.2 , respectively.

The associations between not living with a partner and higher levels of physical inactivity and between manual occupation and lower levels of physical inactivity remained after adjusted analysis. The association between manual occupation and lower levels of physical inactivity was expected, given the nature of the job function. The association between level of physical activity and marital status has been observed by previous studies 68 .

This study has a number of important limitations. The first concerns the instruments used to assess symptoms of depression. Common symptoms of depression, such as sleep and appetite disturbances and lack of energy, are also common during pregnancy, regardless of the mental state of the patient, meaning that pregnant women are more likely to generate a higher score for the items of the CES-D related to the neurovegetative symptoms. A higher cutoff point for the presence of symptoms of depression was adopted to address this problem and minimize bias 52 . However, the rate found by this study is similar to that observed by Pottinger et al. 26 using a questionnaire developed specifically for use with pregnant women (Edinburgh Postnatal Depression Scale - EPDS), indicating that the measure taken to minimize bias was apparently effective. Second, given the cross-sectional nature of the data, caution must be taken in the interpretation of causal relationships between variables. An isolated evaluation during pregnancy may not have the required sensitivity to detect possible associations between symptoms of depression and physical inactivity, given that symptoms of anxiety and depression may develop after chronic and continued exposure to external factors. Finally, the use of a convenience sample limits the generalization of the findings of this study to the general population.

However, it is important to note that level of physical activity, presence of symptoms of depression and anxiety and perceived stress levels were evaluated using instruments already validated and widely used in other studies. Another advantage of this study is the large sample size (1,447 women), which improves the accuracy of findings.

Our findings showed a high rate of symptoms of severe depression and anxiety among this sample of pregnant women, showing that professionals working in prenatal care should be attentive to common mental disorders in pregnant women so as to ensure early diagnosis and treatment and avoid possible negative outcomes for mother and child.

The hypothesis that symptoms of depression and anxiety and stress levels are accentuated in physically inactive women was not confirmed. In fact, physically active women showed higher levels of anxiety, suggesting that the type of physical activity practiced (housework and work-related) is not beneficial to mental health and therefore measures to promote physical activity in pregnant women should bear in mind the demographic profile of this segment of the population. The identification of mood disorders associated with types of physical activity is essential for the development of effective health interventions aimed at promoting the psychological well being of mothers and ensuring a healthy pregnancy and postpartum health. 


\section{Resumen}

El objetivo del estudio fue analizar la asociación entre la salud mental y la inactividad física en 1.447 mujeres, durante el segundo trimestre del embarazo, que respondieron al Cuestionario Internacional de Actividad Física -versión corta, la Escala de Depresión del Centro de Estudios Epidemiológicos, la Escala de Ansiedad de Beck y la Escala de Estrés Percibido. La tasa de in actividad fue baja (39,8\%), síntomas depresivos graves estaban presentes en un $28,8 \%$ de la muestra y el nivel de ansiedad intensa en un 16,9\%. La puntuación media de estrés percibido fue de 24,9. No vivir en pareja $(R P=1,28)$, función manual de trabajo $(R P=0,71) y$ contrariamente a lo esperado, nivel de ansiedad leve $(P R=1,46)$ y mínimo $(P R=1,44)$ mostraron asociación con la inactividad física. No fue encontrada ninguna asociación entre el estrés percibido y los síntomas de la depresión con la inactividad física. Es posible que en las mujeres de la muestra una porción significativa de la actividad física esté relacionada a las actividades domésticas o de empleo, que podrían estar asociadas con mayores niveles de ansiedad.

Salud Mental; Actividad Motora; Embarazo

\section{Contributors}

E. H. M. Takahasi participated in the conception of this study, data analysis and interpretation and the drafting of this article. G. S. Alves, A. A. M. Silva, R. F. L. Batista, V. M. F. Simões and C. M. Del-Ben contributed to data analysis and interpretation and the revision of this article. M. T. S. S. B. Alves contributed to the conception of this study, data analysis and interpretation and the revision of this article. M. A. Barbieri participated in the conception of this study, the critical revision of the intellectual content and approval of the final version of this article.

\section{Acknowledgments}

We are grateful to all of the collaborators of the BRISA Birth Cohort Project and to the CNPq, FAPESP, FAPEMA and PRONEX, for their financial support.

\section{References}

1. ACOG Committee Obstetric Practice. ACOG Committee opinion. Number 267, January 2002: exercise during pregnancy and the postpartum period. Obstet Gynecol 2002; 99:171-3.

2. Davies GA, Wolfe LA, Mottola MF, MacKinnon C. Joint SOGC/CSEP clinical practice guideline: exercise in pregnancy and the postpartum period. Can J Appl Physiol 2003; 28:330-41.

3. Melzer K, Schutz Y, Boulvain M, Kayser B. Physi cal activity and pregnancy cardiovascular adaptations, recommendations and pregnancy outcomes. Sports Med 2010; 40:493-507.
4. Zanchetta LM, Barros MBA, Cesar CLG, Carandina L, Goldbaum M, Alves MCGP. Inatividade física e fatores associados em adultos, São Paulo, Brasil. Rev Bras Epidemiol 2010; 13:387-99.

5. Fell DB, Joseph KS, Armson BA, Dodds L. The impact of pregnancy on physical activity level. Matern Child Health J 2009; 13:597-603.

6. Evenson KR, Savitz DA, Huston SL. Leisure-time physical activity among pregnant women in the US. Paediatr Perinat Epidemiol 2004; 18:400-7.

7. Domingues MR, Barros AJ. Leisure-time physical activity during pregnancy in the 2004 Pelotas Birth Cohort Study. Rev Saúde Pública 2007; 41:173-80. 
8. Tendais I, Figueiredo B, Mota J. Actividade física e qualidade de vida na gravidez. Anál Psicol 2007; 3:489-501.

9. Tendais I, Figueiredo B, Mota J, Conde A. Physical activity, health-related quality of life and depression during pregnancy. Cad Saúde Pública 2011; 27:219-28.

10. Tavares JS, Melo ASO, Amorim MMR, Barros VO, Takito MY, Benício MHD’A, et al. Padrão de atividade física entre gestantes atendidas pela estratégia saúde da família de Campina Grande - PB. Rev Bras Epidemiol 2009; 12:10-9.

11. Dumith SC, Domingues MR, Mendoza-Sassi RA, Cesar JA. Physical activity during pregnancy and its association with maternal and child health indicators. Rev Saúde Pública 2012; 46:327-33.

12. Evenson KR, Wen F. National trends in self-reported physical activity and sedentary behaviors among pregnant women: NHANES 1999-2006. Prev Med 2010; 50:123-8.

13. Borodulin K, Evenson KR, Herring AH. Physical activity patterns during pregnancy through postpartum. BMC Womens Health 2009; 9:32.

14. Watson PE, McDonald BW. Activity levels in pregnant New Zealand women: relationship with socioeconomic factors, well-being, anthropometric measures, and birth outcome. Appl Physiol Nutr Metab 2007; 32:733-42.

15. Takito MY, Benício MHD’A. Physical activity during pregnancy and fetal outcomes: a case-control study. Rev Saúde Pública 2010; 44:90-101.

16. Gaston A, Cramp A. Exercise during pregnancy: A review of patterns and determinants. J Sci Med Sport 2011; 14:299-305.

17. Lin YH, Tsai EM, Chan TF, Chou FH, Lin YL. Health promoting lifestyles and related factors in pregnant women. Chang Gung Med J 2009; 32:650-61.

18. Gouveia R, Martins S, Sandes AR, Nascimento C, Figueira J, Valente $S$, et al. Gravidez e exercício físico: mitos, evidências e recomendações. Acta Med Port 2007; 20:209-14.

19. Poudevigne MS, O'Connor PJ. A review of physical activity patterns in pregnant women and their relationship to psychological health. Sports Med 2006; 36:19-38.

20. Shivakumar G, Brandon AR, Snell PG, SantiagoMunoz P, Johnson NL, Trivedi MH, et al. Antenatal depression: a rationale for studying exercise. Depress Anxiety 2011; 28:234-42.

21. Marcus SM. Depression during pregnancy: rates, risks and consequences - Motherisk Update 2008. Can J Clin Pharmacol 2009; 16:e15-22.

22. Barros MBA, Francisco PMSB, Zanchetta LM, César CLG. Tendências das desigualdades sociais e demográficas na prevalência de doenças crônicas no Brasil, PNAD: 2003-2008. Ciênc Saúde Coletiva 2011; 16:3755-68.

23. Calais SL, Andrade LMB, Lipp MEN. Diferenças de sexo e escolaridade na manifestação de stress em adultos jovens. Psicol Reflex Crit 2003; 16:257-63.

24. Kessler RC, Aguilar-Gaxiola S, Alonso J, Chatterji S, Lee S, Ormel J, et al. The global burden of mental disorders: an update from the WHO World Mental Health (WMH) surveys. Epidemiol Psichiatr Soc 2009; 18:23-33.
25. Bennett HA, Einarson A, Taddio A, Koren G, Ein arson TR. Prevalence of depression during pregnancy: systematic review. Obstet Gynecol 2004 103:698-709.

26. Pottinger AM, Trotman-Edwards H, Younger N. Detecting depression during pregnancy and associated lifestyle practices and concerns among women in a hospital-based obstetric clinic in Jamaica. Gen Hosp Psychiatry 2009; 31:254-61.

27. Almeida MS, Nunes MA, Camey S, Pinheiro AP, Schmidt MI. Transtornos mentais em uma amostra de gestantes da rede de atenção básica de saúde no Sul do Brasil. Cad Saúde Pública 2012; 28 . 385-93.

28. Araújo DMR, Pacheco AHRN, Pimenta AM, Kac G. Prevalência e fatores associados a sintomas de an siedade em uma coorte de gestantes atendidas em um centro de saúde do município do Rio de Janeiro. Rev Bras Saúde Matern Infant 2008; 8:333-40.

29. Woods SM, Melville JL, Guo Y, Fan MY, Gavin A. Psychosocial stress during pregnancy. Am J Obstet Gynecol 2010; 202:61.e1-7.

30. Rodrigues OMPR, Schiavo RA. Stress na gestação e no puerpério: uma correlação com a depressão pós-parto. Rev Bras Ginecol Obstet 2011; 33:252-7.

31. Segato L, Andrade A, Vasconcellos DIC, Matias TS, Rolim MKSB. Ocorrência e controle do estresse em gestantes sedentárias e fisicamente ativas. Rev Educ Fís 2009; 20:121-9.

32. Tegethoff M, Greene N, Olsen J, Meyer AH, Meinlschmidt G. Maternal psychosocial adversity during pregnancy is associated with length of gestation and offspring size at birth: evidence from a population-based cohort study. Psychosom Med 2010; 72:419-26.

33. Bloch M, Rotenberg N, Koren D, Klein E. Risk factors associated with the development of postpartum mood disorders. J Affect Disord 2005; 88:9-18.

34. Strohle A. Physical activity, exercise, depression and anxiety disorders. J Neural Transm 2009; 116:777-84.

35. Knöchel C, Oertel-Knochel V, O’Dwyer L, Prvulovic D, Alves G, Kollmann B, et al. Cognitive and behavioural effects of physical exercise in psychiatric patients. Prog Neurobiol 2012; 96:46-68.

36. Deslandes A, Moraes H, Ferreira C, Veiga H, Silveira H, Mouta R, et al. Exercise and mental health: many reasons to move. Neuropsychobiology 2009; 59:191-8.

37. Byrne A, Byrne DG. The effect of exercise on depression, anxiety and other mood states: a review. J Psychosom Res 1993; 37:565-74.

38. Rimer J, Dwan K, Lawlor DA, Greig CA, McMurdo M, Morley W, et al. Exercise for depression. Cochrane Database Syst Rev 2012; (7):CD004366.

39. Larun L, Nordheim LV, Ekeland E, Hagen KB, Heian F. Exercise in prevention and treatment of anxiety and depression among children and young people. Cochrane Database Syst Rev 2006; (3):CD004691.

40. Jacka FN, Mykletun A, Berk M. Moving towards a population health approach to the primary prevention of common mental disorders. BMC Med 2012; 10:149. 
41. Muhsen K, Garty-Sandalon N, Gross R, Green MS Psychological distress is independently associated with physical inactivity in Israeli adults. Prev Med 2010; 50:118-22.

42. Hamer M, Stamatakis E, Steptoe A. Dose-response relationship between physical activity and menta health: the Scottish Health Survey. Br J Sports Med 2009; 43:1111-4.

43. Poudevigne MS, O'Connor PJ. Physical activity and mood during pregnancy. Med Sci Sports Exerc 2005; 37:1374-80.

44. Loprinzi PD, Fitzgerald EM, Cardinal BJ. Physical activity and symptoms of depression among pregnant women from the National Health and Nutrition Examination Survey 2005-2006. J Obstet Gynecol Neonatal Nurs 2012; 41:227-35.

45. Koniak-Griffin D. Aerobic exercise, psychological well-being, and physical discomforts during adolescent pregnancy. Res Nurs Health 1994; 17: 253-63.

46. Robledo-Colonia AF, Sandoval-Restrepo N Mosquera-Valderrama YF, Escobar-Hurtado C, Ramirez-Velez R. Aerobic exercise training during pregnancy reduces depressive symptoms in nulliparous women: a randomised trial. J Physiother 2012; 58:9-15.

47. Demissie Z, Siega-Riz AM, Evenson KR, Herring AH, Dole N, Gaynes BN. Physical activity and depressive symptoms among pregnant women: the PIN3 study. Arch Womens Ment Health 2011; 14:145-57.

48. Goodwin A, Astbury J, McMeeken J. Body image and psychological well-being in pregnancy. A comparison of exercisers and non-exercisers. Aust N Z J Obstet Gynaecol 2000; 40:442-7.

49. Matsudo S, Araújo T, Matsudo V, Andrade D, Andrade E, Oliveira LC, et al. Questionário Internacional de Atividade Física (IPAQ): estudo de validade e reprodutibilidade no Brasil. Rev Bras Ativ Fís Saúde 2001; 6:5-18.

50. Guidelines for the data processing and analysis of the International Physical Activity Questionnaire (IPAQ) - short and long forms. http://www.ipaq. ki.se/scoring.pdf (accessed on 17/Apr/2012).

51. Radloff LS. The CES-D scale: a self-report depres sion scale for research in the general population. Appl Psychol Meas 1977; 1:385-401.

52. Li D, Liu L, Odouli R. Presence of depressive symptoms during early pregnancy and the risk of preterm delivery: a prospective cohort study. Hum Reprod 2009; 24:146-53.

53. Beck AT, Epstein N, Brown G, Steer RA. An inventory for measuring clinical anxiety: psychometric properties. J Consult Clin Psychol 1988; 56:893-7.

54. Magan I, Sanz J, Garcia-Vera MP. Psychometric properties of a Spanish version of the Beck Anxiety Inventory (BAI) in general population. Span J Psychol 2008; 11:626-40.
55. Beck NC, Siegel LJ, Davidson NP, Kormeier S, Bre itenstein A, Hall DG. The prediction of pregnancy outcome: maternal preparation, anxiety and attitudinal sets. J Psychosom Res 1980; 24:343-51.

56. Cohen S, Kamarck T, Mermelstein R. A global measure of perceived stress. J Health Soc Behav 1983 24:385-96.

57. Luft CDB, Sanches SO, Mazo GZ, Andrade A. Versão brasileira da Escala de Estresse Percebido: tradução e validação para idosos. Rev Saúde Pública 2007; 41:606-15.

58. Rondo PH, Ferreira RF, Nogueira F, Ribeiro MC, Lobert H, Artes R. Maternal psychological stress and distress as predictors of low birth weight, prematurity and intrauterine growth retardation. Eur J Clin Nutr 2003; 57:266-72.

59. World Health Organization. Global strategy on diet, physical activity and health: physical activity. http://www.who.int/dietphysicalactivity/pa/en/ index.html (accessed on 05/May/2010).

60. Araújo TM, Pinho PS, Almeida MMG. Prevalência de transtornos mentais comuns em mulheres e sua relação com as características sociodemográficas e o trabalho doméstico. Rev Bras Saúde Matern Infant 2005; 5:337-48.

61. Jablonski B. A divisão de tarefas domésticas entre homens e mulheres no cotidiano do casamento. Psicol Ciênc Prof 2010; 30:262-75.

62. Lennon MC, Rosenfield S. Women and mental health: the interaction of job and family conditions. J Health Soc Behav 1992; 33:316-27.

63. Marcondes WB, Rotenberg L, Portela LF, Moreno CRC. O peso do trabalho feminino "leve" à saúde. São Paulo Perspect 2003; 17:91-101.

64. Ludermir AB. Inserção produtiva, gênero e saúde mental. Cad Saúde Pública 2000; 16:647-59.

65. Jefferis BJ, Nazareth I, Marston L, Moreno-Kustner B, Bellón JA, Svab I, et al. Associations between unemployment and major depressive disorder: evidence from an international, prospective study. Soc Sci Med 2011; 73:1627-34.

66. Glass J, Fujimoto T. Housework, paid work, and depression among husbands and wives. J Health Soc Behav 1994; 35:179-91

67. Blay SL, Marchesoni MS. Association among physical, psychiatric and socioeconomic conditions and WHOQOL-Bref scores. Cad Saúde Pública $2011 ; 27: 677-86$.

68. Petersen AM, Leet TL, Brownson RC. Correlates of physical activity among pregnant women in the United States. Med Sci Sports Exerc 2005; 37: 1748-53.

Submitted on 06/Aug/2012

Final version resubmitted on 18/Feb/2013

Approved on 04/Mar/2013 